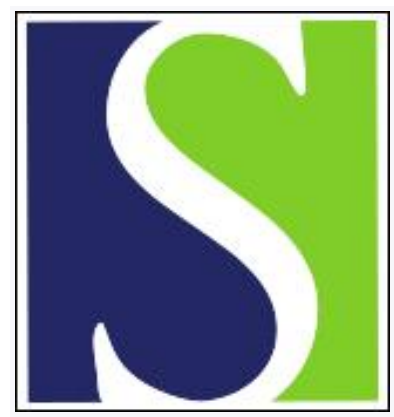

Scand J Work Environ Health 2014;40(4):361-369

https://doi.org/10.5271/sjweh.3427

Published online: 01 Apr 2014, Issue date: 01 Jul 2014

Work-related gender differences in physician-certified sick leave: a prospective study of the general working population in Norway

by Sterud T

The gender-segregated labor market may contribute to the gender difference in sick leave observed in many European countries, but working conditions have rarely been studied as a cause of this difference. This nationwide study provides evidence of a substantial relationship between work-related psychosocial factors and excess risk of physician-certified sick leave among women. Mechanical exposure had a small overall impact.

Affiliation: National Institute of Occupational Health, PO Box 8149 Dep, NO-0033 Oslo, Norway. tom.sterud@stami.no

Refers to the following texts of the Journal: 2009;35(5):334-341

1994;20(3):213-215 2010;36(1):34-41 2010;36(5):394-403

2012;38(6):582-589

Key terms: gender; gender difference; long-term sick leave; mechanical process; Norway; physician-certified sick leave; prospective study; psychosocial factor; risk factor; sick leave; sickness absence; sickness absence; work-related gender difference; working population; workplace

This article in PubMed: www.ncbi.nlm.nih.gov/pubmed/24691748

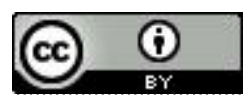




\title{
Work-related gender differences in physician-certified sick leave: a prospective study of the general working population in Norway
}

\author{
by Tom Sterud, $P h D^{1}$
}

Sterud T. Work-related gender differences in physician-certified sick leave: a prospective study of the general working population in Norway. Scand J Work Environ Health. 2014;40(4):361-369. doi:10.5271/sjweh.3427

Objectives This study aimed to examine gender differences in physician-certified sick leave and the extent to which these differences can be explained by work-related psychosocial and mechanical risk factors.

Methods Randomly drawn from the general population in Norway, the cohort comprised working men and women aged $18-69$ years $(\mathrm{N}=12255$, response rate at baseline $=60.9 \%)$. Eligible respondents were interviewed in 2009 and registered with an active employee relationship of $\geq 100$ actual working days in 2009 and 2010 $(\mathrm{N}=3688$ men and 3070 women). The study measured 11 work-related psychosocial factors and 11 mechanical exposures, and outcomes of interest were physician-certified general sick leave (GSL) $>0$ days and long-term sick leave (LTSL) $\geq 40$ working days during 2010 .

Results Women reported a significantly higher level of exposure to 9 of the 11 psychosocial factors evaluated. For mechanical factors, the reporting was mixed. After controlling for age, educational level, sick leave during 2009, housework, working hours and family status, a 1.7-fold risk for GSL and LTSL were found among women. In comparison with the initial model, adjusting for psychosocial factors reduced the excess risk by $21 \%$ and $27 \%$ for GSL and LTSL, respectively. The total effect of mechanical factors was negligible. Differences between occupations held by women and men explained an additional one-tenth of the excess risk for LTSL among women.

Conclusions Work-related psychosocial factors contributed significantly to a higher level of GSL and LTSL among women. The most important factors were demands for hiding emotions, emotional demands, and effortpayment imbalance.

Key terms long-term sick leave; mechanical process; psychosocial factor; risk factor; sickness absence; workplace.

Higher rates of female sick leave have been reported in Scandinavia (1-4) and other European countries (5). The gender-segregated labor market has been discussed as an important factor in observed gender differences in sick leave (6). According to official Norwegian statistics, approximately $80 \%$ of those employed in human health and social work sectors and activities are women, and $>80 \%$ of those employed in construction and manufacturing sectors are men (7). Similar numbers have been reported in other Nordic countries $(8,9)$. However, only a few nationwide studies have been undertaken, and more knowledge is needed about the impact of specific risk factors in the workplace on gender differences in sick leave (10).

Gender differences in sick leave could be caused by differences in exposure to physical workloads (ie, mechanical exposure) and psychosocial factors in the workplace $(11,12)$. Men and women are typically involved in different types of jobs with divergent work environment characteristics; gender differences in exposure to psychosocial and physical risk factors exist, even when accounting for differences in job titles $(8,13)$. Jobs held by men are generally more physically demanding (14), and this has been reported as a risk factor in several studies (15-18). However, many female jobs are also characterized by physically strenuous work tasks, such as those found in nursing (eg, manually moving patients), and women often perform tasks that require precision and are repetitive in nature (13). Gender differences may also be expected for a range of psychosocial factors in the workplace. Studies have shown there are gender differences in exposure to risk factors, such as those proposed in Karasek's much-studied Job Demand-Control-Support model $(8,13)$. In particular,

1 National Institute of Occupational Health, Oslo, Norway.

Correspondence to: Tom Sterud, National Institute of Occupational Health, PO Box 8149 Dep, NO-0033 Oslo, Norway. [E-mail: tom. sterud@stami.no] 
women are found to report lower levels of job control than men (14). Furthermore, women are more often involved in emotionally demanding "people work" (eg, nurses, service workers, etc.), and female jobs are often characterized by relatively lower levels of job rewards, such as wages and career opportunities (2). Low job control (11), emotional demands $(19,20)$, and effort-reward imbalance (21) have been reported as risk factors for sick leave in prospective studies and may contribute to the excess risk of sick leave observed among women. Overall, however, it is unclear whether men or women have the least healthy jobs $(14,22)$.

During the last two decades, a few prospectively designed studies have examined whether differences pertaining to working conditions or occupational exposure can explain the excess risk of physician-certified sick leave among women. Laaksonen et al $(23,24)$ studied sick leave among municipal workers in the capital of Finland. In the first study, adjusting for self-reported exposure to physical work demands but not psychosocial working conditions explained a substantial part of the female excess in sick leave of both short and longer duration (adjusting for age and socioeconomic status). In the second study, which adjusted for occupation by means of fixed regression, $33-50 \%$ of the excess risk of different lengths of sick leave among women was explained by differences between occupations held by men and women. In a general working population study from Denmark, Labriola et al (10) found that adjusting for self-reported exposure to psychosocial working conditions but not physical work demands explained about one-third of the female excess in sick leave periods of $\geq 8$ weeks (adjusted for age and family status and socioeconomic position). Three studies have been conducted on different populations in Norway. Mastekaasa et al $(22,25)$ studied gender differences in sick leave periods of $\geq 4$ days duration among Norwegian civil servants and sick leave periods of $>2$ weeks in the general working population. Controlling for occupation by means of fixed regression explained approximately $40 \%$ of the excess risk among female civil servants (25), whereas controlling for occupation had the opposite effect in the general working population study and slightly increased the gender difference (22). However, a study from Oslo concluded that differences related to working conditions or occupation could not explain the observed gender differences in sick leave spells $>16$ days (26). Hence, the effect of occupation and working conditions on gender differences in sick leave of varying length is inconclusive.

The aim of the present study was therefore to address the gender difference in the risk of physician-certified sick leave of different lengths [ie, all sick leave, irrespective of duration, and long-term sick leave (LTSL) exceeding 40 days a year] and the extent to which differences were explained by a wide range of work- related psychosocial and mechanical risk factors and occupation in a nationwide general working population sample. In addition to age and education level, potential confounders, such as working hours (14), family status, and housework (27), were taken into account.

\section{Methods}

\section{Study design and study population}

Data were taken from Statistics Norway's nationwide Survey of Level of Living: Working Conditions. Eligible respondents were community-living Norwegian residents aged 18-69 years. In 2009, a gross sample of 20136 was randomly drawn from this population. Of these, 12255 (60.9\%) persons were interviewed between 22 June 2009 and 9 January 2010. The baseline sample was compared to the gross sample. Response by region varied by less than 0.6 percentage points (pp). There was a slight overrepresentation of women (1.5 pp) and respondents aged 45-66 (2.7 pp) and a underrepresentation of respondents age 25-44 (2.7 pp).

Data on sick leave (ie, the total number of lost working days due to physician-certified sick leave during a calendar year) was obtained from the Norwegian Labour and Welfare Administration's sickness benefit register. The register includes all workers aged 16-69 years living in Norway and registered with an active employee relationship. Respondents who were in paid work for $\geq 1$ hour during the reference week, or temporarily absent from such work, and were registered with an active employee relationship of $\geq 100$ actual working days in each year (2009 and 2010) constituted the follow-up sample in the present paper $(\mathrm{N}=6758)$.

\section{Measures}

Sick leave. General sick leave (GSL) was defined as physician-certified sickness leave irrespective of length. LTSL was defined as physician-certified sickness absence for $\geq 40$ actual working days during 2010: the year after the initial survey data was collected. In Norway, employees receive full compensation from the first day of sick leave. Employees have the right to self-certification of sick leave up to 3 or 8 consecutive days, depending on their employers' settlement with the Norwegian Labour and Welfare Administration. If the absence period exceeds the specified number of days, a physician's certificate is required.

Occupation was based on an open questionnaire and coded by Statistics Norway into professional title in accordance with the International Standard Classifica- 
Table 1. Description of the sick leave and explanatory variables for men ( $N=3688)$ and women $(N=3070)$. [D=Cohen's d; $S D=s t a n d a r d ~ d e v i a t i o n]$

\begin{tabular}{|c|c|c|c|c|c|c|c|}
\hline & \multirow[t]{2}{*}{ Range } & \multicolumn{2}{|c|}{ Men } & \multicolumn{2}{|c|}{ Women } & \multirow[t]{2}{*}{$\mathrm{D}$} & \multirow[t]{2}{*}{ P-value } \\
\hline & & Mean & SD & Mean & SD & & \\
\hline \multicolumn{8}{|l|}{ Outcome variables } \\
\hline General sick leave (GSL) a & $0-1$ & 0.269 & 0.44 & 0.432 & 0.49 & & $<0.01$ \\
\hline Long-term sick leave (LTSL) b & $0-1$ & 0.072 & 0.26 & 0.121 & 0.33 & & $<0.01$ \\
\hline \multicolumn{8}{|l|}{ Confounder variables } \\
\hline Age & $18-69$ & 43.68 & 11.71 & 44.04 & 11.23 & & 0.20 \\
\hline Working hours/week & $0-90$ & 40.83 & 8.33 & 36.19 & 7.62 & & $<0.01$ \\
\hline Unpaid work/week & $1-4$ & 1.77 & 0.77 & 2.32 & 0.82 & & $<0.01$ \\
\hline Educational level & $1-5$ & 3.16 & 1.19 & 3.26 & 1.14 & & $<0.01$ \\
\hline Family status ${ }^{c}$ & & & & & & & $<0.01$ \\
\hline Living alone & $0-1$ & 0.20 & 0.40 & 0.18 & 0.38 & & \\
\hline Married/cohabiting without children & $0-1$ & 0.31 & 0,46 & 0.32 & 0.47 & & \\
\hline Single parent & $0-1$ & 0.03 & 0.17 & 0.08 & 0.27 & & \\
\hline Married/cohabiting with children $<=6$ year & $0-1$ & 0.22 & 0,41 & 0.17 & 0.38 & & \\
\hline Married/cohabiting with children $>6$ years & $0-1$ & 0.24 & 0.43 & 0.25 & 0.43 & & \\
\hline \multicolumn{8}{|l|}{ Explanatory variables } \\
\hline \multicolumn{8}{|l|}{ Psychosocial factors } \\
\hline Job demands & $1-5$ & 3.55 & 0.94 & 3.75 & 0.92 & 0.22 & $<0.01$ \\
\hline Job control & $1-5$ & 2.41 & 0.78 & 2.65 & 0.78 & 0.30 & $<0.01$ \\
\hline Leader support & $1-5$ & 1.93 & 0.87 & 1.95 & 0.90 & 0.03 & 0.28 \\
\hline Role conflict & $1-5$ & 2.04 & 0.81 & 2.11 & 0.83 & 0.09 & $<0.01$ \\
\hline Emotional demands & $1-4$ & 2.03 & 0.96 & 2.61 & 1.09 & 0.57 & $<0.01$ \\
\hline Demands for hiding emotions & $1-5$ & 2.08 & 0.92 & 2.46 & 0.99 & 0.40 & $<0.01$ \\
\hline Monotonous work & $1-5$ & 2.21 & 1.44 & 2.29 & 1.49 & 0.05 & $<0.05$ \\
\hline Possibilities for development & $1-4$ & 1.72 & 0.57 & 1.80 & 0.60 & 0.14 & $<0.01$ \\
\hline Effort-pay imbalance & $1-5$ & 2.42 & 1.30 & 2.65 & 1.38 & 0.17 & $<0.01$ \\
\hline Bullying ${ }^{c}$ & $0-1$ & 0.03 & 0.16 & 0.03 & 0.17 & 0.01 & 0.38 \\
\hline Sexual harassment ${ }^{c}$ & $0-1$ & 0.01 & 0.12 & 0.05 & 0.21 & 0.20 & $<0.01$ \\
\hline \multicolumn{8}{|l|}{ Mechanical factors } \\
\hline Neck flexion & $1-4$ & 1.31 & 0.73 & 1.42 & 0.86 & 0.14 & $<0.01$ \\
\hline Hand/arm repetition & $1-4$ & 1.98 & 1.23 & 2.07 & 1.29 & 0.07 & $<0.01$ \\
\hline Hands above shoulders & $1-4$ & 1.24 & 0.65 & 1.18 & 0.58 & -0.10 & $<0.01$ \\
\hline Squatting/kneeling & $1-4$ & 1.25 & 0.64 & 1.22 & 0.59 & -0.05 & $<0.05$ \\
\hline Standing & $1-4$ & 2.04 & 1.23 & 2.25 & 1.30 & 0.17 & $<0.01$ \\
\hline Upper body forward bend & $1-4$ & 1.15 & 0.50 & 1.19 & 0.58 & 0.07 & $<0.01$ \\
\hline Awkward lifting & $1-4$ & 1.16 & 0.51 & 1.19 & 0.55 & 0.06 & $<0.05$ \\
\hline Heavy lifting & $1-4$ & 1.40 & 0.82 & 1.22 & 0.60 & -0.25 & $<0.01$ \\
\hline Heavy physical work & $1-4$ & 1.24 & 0.62 & 1.16 & 0.54 & -0.14 & $<0.01$ \\
\hline Whole-body vibration & $1-4$ & 1.12 & 0.53 & 1.02 & 0.23 & -0.26 & $<0.01$ \\
\hline Lifting persons $^{c}$ & $0-1$ & 0.02 & 0.12 & 0.14 & 0.34 & 0.54 & $<0.01$ \\
\hline
\end{tabular}

a Physician-certified sick leave $>0$ days during 2010.

b Physician-certified sick leave $\geq 40$ days during 2010 .

c For categorical variables (range $0-1$ ), the mean score equals the proportion of respondents registered with the value 1 (ie, the percentage of respondents who are exposed).

tion of Occupations (ISCO-88), and was recoded into 26 occupational groups based on 2-digit codes (table 2).

Perceived mechanical workload was measured with 11 items developed by an expert group in a Nordic cooperation project (28): (i) "Do you work with your head bent forward?" (neck flexion); (ii) "Does your work involve repeated hand or arm movement?" (hand/arm repetition) (response categories: yes/no); (iii) "Do you work with your hands raised to shoulder height or higher?" (hands above shoulder height); (iv) "Do you need to squat or kneel in the course of your work?" (squatting/kneeling); (v) "Do you work standing up?"; (standing); (vi) "Do you work in positions where you are leaning forward without supporting yourself on your hands or arms?" (upper-body forward bend); (vii) "Do you have to lift things in uncomfortable positions?" (awkward lifting); and (viii) "Does your work involve so much effort that it causes you to breathe more rapidly?" (heavy physical work); (ix) "Are you, in your day-to-day work, exposed to vibrations that cause your whole body to shake, eg, from a tractor, forklift truck or other piece of machinery?" (whole-body vibration) (response categories: yes/no). "Yes" respondents were asked to estimate the proportion of the working day during which they were exposed (response categories: almost the whole time, $3 / 4,1 / 2,1 / 4$, and very little of the work day). Scores were categorized into "none or very little of the work day", 
Table 2. Distribution of men and women by occupational group.

\begin{tabular}{|c|c|c|c|c|c|}
\hline & \multicolumn{2}{|c|}{ Men a } & \multicolumn{2}{|c|}{ Women a } & \multirow{2}{*}{$\frac{\text { Women }^{\mathrm{b}}}{\%}$} \\
\hline & $\mathrm{N}$ & $\%$ & $\mathrm{~N}$ & $\%$ & \\
\hline $\begin{array}{l}\text { Legislator / senior } \\
\text { official public administra- } \\
\text { tion / interest organization }\end{array}$ & 8 & 0.2 & 6 & 0.2 & 42.9 \\
\hline $\begin{array}{l}\text { Corporate manager large / } \\
\text { medium-sized enterprise }\end{array}$ & 388 & 10.5 & 187 & 6.1 & 32.5 \\
\hline $\begin{array}{l}\text { Corporate manager } \\
\text { small enterprise }\end{array}$ & 146 & 4.0 & 54 & 1.8 & 27.0 \\
\hline $\begin{array}{l}\text { Physical, math, engineer- } \\
\text { ing science professional }\end{array}$ & 277 & 7.5 & 83 & 2.7 & 23.1 \\
\hline $\begin{array}{l}\text { Life science health } \\
\text { professional }\end{array}$ & 53 & 1.4 & 111 & 3.6 & 67.7 \\
\hline Teaching professional & 87 & 2.4 & 104 & 3.4 & 54.5 \\
\hline $\begin{array}{l}\text { Public service } \\
\text { administrative professional }\end{array}$ & 42 & 1.1 & 82 & 2.7 & 66.1 \\
\hline Other professional & 168 & 4.6 & 162 & 5.3 & 49.1 \\
\hline $\begin{array}{l}\text { Engineering science } \\
\text { associate professional }\end{array}$ & 378 & 10.2 & 69 & 2.2 & 15.4 \\
\hline $\begin{array}{l}\text { Life science and health } \\
\text { associate professional }\end{array}$ & 46 & 1.2 & 226 & 7.4 & 83.1 \\
\hline $\begin{array}{l}\text { Teaching associate } \\
\text { professional }\end{array}$ & 114 & 3.1 & 298 & 9.7 & 72.3 \\
\hline $\begin{array}{l}\text { Executive officer } \\
\text { administration business / } \\
\text { social work }\end{array}$ & 399 & 10.8 & 482 & 15.7 & 54.7 \\
\hline Office clerk & 143 & 3.9 & 226 & 7.4 & 61.2 \\
\hline Customer services clerk & 13 & 0.4 & 26 & 0.8 & 66.7 \\
\hline $\begin{array}{l}\text { Service worker and shop / } \\
\text { market sales worker }\end{array}$ & 189 & 5.1 & 581 & 18.9 & 75.5 \\
\hline $\begin{array}{l}\text { Salesperson / } \\
\text { demonstrator }\end{array}$ & 115 & 3.1 & 156 & 5.1 & 57.6 \\
\hline $\begin{array}{l}\text { Agricultural and forestry } \\
\text { worker / fish farmer etc }\end{array}$ & 22 & 0.6 & 11 & 0.4 & 33.3 \\
\hline $\begin{array}{l}\text { Craft and related trades } \\
\text { worker }\end{array}$ & 227 & 6.2 & 5 & 0.2 & 2.2 \\
\hline $\begin{array}{l}\text { Metal machinery and } \\
\text { related trades worker }\end{array}$ & 344 & 9.3 & 12 & 0.4 & 3.4 \\
\hline $\begin{array}{l}\text { Precision, handicraft, } \\
\text { printing and related trades } \\
\text { worker }\end{array}$ & 17 & 0.5 & 15 & 0.5 & 46.9 \\
\hline $\begin{array}{l}\text { Other craft and related } \\
\text { trades worker }\end{array}$ & 37 & 1.0 & 10 & 0.3 & 21.3 \\
\hline $\begin{array}{l}\text { Stationary-plant and } \\
\text { related operator }\end{array}$ & 98 & 2.7 & 7 & 0.2 & 6.7 \\
\hline $\begin{array}{l}\text { Machine operator / } \\
\text { assembler }\end{array}$ & 76 & 2.1 & 30 & 1.0 & 28.3 \\
\hline $\begin{array}{l}\text { Driver / mobile-plant } \\
\text { operator }\end{array}$ & 170 & 4.6 & 7 & 0.2 & 4.0 \\
\hline $\begin{array}{l}\text { Sales and services elemen- } \\
\text { tary occupations }\end{array}$ & 34 & 0.9 & 80 & 2.6 & 70.2 \\
\hline $\begin{array}{l}\text { Armed forces and } \\
\text { unspecified }\end{array}$ & 97 & 2.6 & 40 & 1.3 & 29.2 \\
\hline Total & 3688 & 100 & 3070 & 100 & 45.4 \\
\hline
\end{tabular}

" $1 / 4$ of the work day", " $1 / 2$ of the work day" and " $\geq 3 / 4$ of the work day". (x) Heavy lifting was measured with a single item: "Do you have to lift anything that weighs $>20 \mathrm{~kg}$ on a daily basis?" (response categories: $0,1-4$, 5-19; $\geq 20$ times/day, no). (xi) "Yes" respondents were also asked: "Are you normally lifting people?" (response categories yes/no) (lifting persons).
Perceived psychosocial factors at work were measured with several items from the General Nordic Questionnaire for psychological and social factors at work (QPS Nordic) (29). Quantitative demands (2 items, $\alpha=0.70$ ): (i) "How often do you have to work quickly?" and (ii) "How often do you have too much to do?" Role conflict (3 items, $\alpha=0.64$ ): (i) "How often do you receive contradictory requests from two or more people?"; (ii) "How often are you given tasks without being given sufficient tools and resources to complete them?"; and (iii) "How often do you have to do things that you think should be done in a different way?" Supportive leadership (3 items, $\alpha=0.70$ ): (i) "If needed, how often can you get support and help from your immediate superior with your work?"; (ii) "Does your immediate superior appreciate your achievements at work?"; and (iii) "Does your immediate superior treat employees fair and impartially?" Job control (4 items $(\alpha=0.71)$ : (i) "To what extent can you decide the pace at which you work"; (ii) "To what extent can you influence decisions that are important to your work?"; (iii) "To what extent are you free to decide how to go about your work?"; and (iv) "To what extent are you free to decide your own tasks?" (Answer categories were: "to a very great extent," "to a great extent," "to some extent," "not really," and "hardly at all.").

Effort-payment imbalance was based on a modified single item from the effort-reward imbalance questionnaire (30): "To what extent do you agree or disagree with the following statement? My salary is appropriate to my efforts and performance at work." (Answer categories: totally agree, somewhat agree, neither agree nor disagree, somewhat disagree, totally disagree).

Other dimensions were measured with items developed by Statistics Norway. Emotional demands: "In your work, to what extent do you need to deal with strong feelings such as sorrow, anger, desperation, frustration, and so on from customers, clients, or other people who are not employed at your workplace?" (Answer categories: "to a very great extent, "to a great extent," "to some extent," "not really" and "not at all"). Demands for hiding emotions: "In your work, to what extent do you need to conceal negative feelings such as anger, irritation, frustration, and so on for customers, clients, or other people who are not employed at your workplace?" (Answer categories were "to a great extent," "to some extent," "not really" and "not at all). Possibilities for development ( 2 items, $\alpha=0.72$ ): "In your job, how good are your opportunities to (i) "develop your skills in the areas that interest you" and (ii) "make use of the skills, knowledge, and experience that you have gained through your education and past work?" (Answer categories: very good, good, poor, or very poor). Bullying (2 items): "Do you sometimes: (i) "get bothered or teased in an unpleasant way by your colleagues?" and (ii) "get bothered or teased in an unpleasant way by superiors?" 
Sexual harassment (1 item): "Do you sometimes receive unwanted sexual attention, comments, etc. at your workplace?" (Answer categories: yes, once or more a week; yes, once or more a month; no). All factors were used as continuous variables and higher scores indicate unfavorable exposure, except for a dichotomous variable for bullying and sexual harassment.

\section{Confounder measures}

Educational level was based on administrative register data coded into five educational levels and used as a continuous measure. Gender and age were based on self-reported information. Family status was coded as: living alone, married/cohabiting without children, single parent, married/cohabiting with youngest children $\leq 6$ years, and married/cohabiting with youngest children $>6$ years. Actual weekly working hours (working hours/ week), including paid overtime and extra work done at home and related to the main job, was measured with a single item and used as a continuous measure. Hours spent on housework each week (housework hours/week) was measured with a single item ranging from $1(<5$ hours/week) to 4 (>19 hours/week).

\section{Statistical analysis}

Gender differences in self-reported work-related factors were reported as Cohen's d. Continuous variables were tested with t-tests, and chi-square tests were used for categorical variables. Univariate analyses of variance (UNIANOVA) were used to compare mean scores for work-related psychosocial variables by gender, adjusted for occupation. The associations between gender and GSL and LTSL were calculated as odds ratios (OR) with $95 \%$ confidence intervals $(95 \%$ CI). Multiple logistic regression analyses were conducted. First, the initial models were adjusted for age, education, working hours, working hours squared, housework and family status (initial OR). Next, each work-related psychosocial factor was adjusted for, one at a time and then simultaneously. The same procedure was applied for the work-related mechanical factors. Finally, all factors were added simultaneously [adjusted $\left.\mathrm{OR}\left(\mathrm{OR}_{\mathrm{adj}}\right)\right]$. The impact (\%) of each separate factor or set of factors on the gender difference in GSL and LTSL was estimated as the percentage change in $\mathrm{OR}$ when comparing $\mathrm{OR}_{\mathrm{adj}}$ to the initial $\mathrm{OR}\left(\mathrm{OR}_{\text {init }}\right)$ using the formula: $\left(\mathrm{OR}_{\text {adj }}-\mathrm{OR}_{\text {init }}\right)$ $/\left(\mathrm{OR}_{\text {init }}-1\right) \times 100$. Statistical analyses were conducted with SPSS Statistics for Windows, version 20.0 (IBM Corporation, Armonk, NY, USA).

\section{Results}

In total, $26.9 \%$ (994 individuals) of men and $43.2 \%$ (1327 individuals) of women were classified as taking GSL during 2010, and 7.2\% (264 individuals) of men and $12.1 \%$ (371 individuals) of women were classified as taking LTSL. Among respondents with no GSL or LTSL in $2009,17.2 \%$ (445 individuals) of men and $21.4 \%$ (476 individuals) of women were classified as taking GSL during 2010, and $5.2 \%$ (177 individuals) of men and $9.1 \%$ (250 individuals) of women were classified as taking LTSL, respectively.

As shown in table 1, there were statistically significant differences between men and women for all potential confounders except age. Women had a higher mean level of education, a lower level of working hours/week, a higher level of housework hours/week and were more often registered as single parents. Statistically significant gender differences were observed for all explanatory variables except leader support and bullying. Women reported a significantly higher level of exposure to 9 of the 11 psychosocial factors evaluated. The largest difference was observed for emotional demands (Cohen's $\mathrm{d}=0.57$ ).

Adjusting for occupation reduced the observed gender differences in perceived psychosocial exposure by approximately $60 \%$ for emotional demands and demands for hiding emotions and by nearly $50 \%$ for effort-payment imbalance. The lowest reduction was observed for job demands (7\%) and the highest for role conflict (87\%) (table not shown). For mechanical factors, the reporting was mixed. Women reported a significantly higher level of exposure to six of the 11 work-related mechanical factors. The observed mean differences ranged from Cohen's d=0.06 (awkward lifting) to 0.17 (standing). Men reported a significantly higher level of exposure to heavy physical work, heavy lifting, and whole-body vibration (Cohen's $d$ ranging from $0.14-0.26$ ).

Table 3 shows that women had an increased risk of both GSL (OR 1.75, 95\% CI 1.54-1.98) and LTSL (OR $1.66,95 \%$ CI 1.36-2.102) compared with men (adjusted for age, educational level, registered GSL or LTSL during 2009 ,working hours, working hours squared, housework and family status). In comparison with the initial model, adjusting for psychosocial factors reduced the OR by $21 \%$ and $27 \%$ for GSL and LTSL, respectively. The most important factors were demands for hiding emotions, emotional demands, and effort-payment imbalance, which contributed to a $13-21 \%$ reduction in OR for both GSL and LTSL. In addition, low job control and quantitative demands contributed to a $4-8 \%$ reduction in OR for both GSL and LTSL. In comparison with the initial model, adjusting for mechanical factors increased the gender difference for GSL by $6 \%$ and had no impact on the gender difference for LTSL. Mechanical factors asso- 
Table 3. Multiple logistic regression: general sick leave (GSL) ${ }^{a}$ and long-term sick leave (LTSL) a regressed on gender: the effect of adjusting for mechanical and psychosocial working conditions. [OR=0dds ratio; $95 \% \mathrm{Cl}=95 \%$ confidence interval;

\begin{tabular}{|c|c|c|c|c|c|c|}
\hline & \multicolumn{3}{|c|}{$\mathrm{GSL}^{\mathrm{a}}$} & \multicolumn{3}{|c|}{ LTSL b } \\
\hline & OR & $95 \% \mathrm{Cl}$ & $\begin{array}{c}\% \\
\text { change }\end{array}$ & OR & $95 \% \mathrm{Cl}$ & $\begin{array}{c}\% \\
\text { change }\end{array}$ \\
\hline \multicolumn{7}{|l|}{ Initial model d } \\
\hline Men & 1.00 & & & 1.00 & & \\
\hline Women & 1.75 & $1.54-1.98$ & & 1.66 & $1.36-2.02$ & \\
\hline \multicolumn{7}{|c|}{$\begin{array}{l}\text { Psychosocial } \\
\text { factors }\end{array}$} \\
\hline Job demands & 1.71 & $1.51-1.94$ & -0.05 & 1.61 & $1.31-1.97$ & -0.08 \\
\hline Job control & 1.72 & $1.52-1.95$ & -0.04 & 1.62 & $1.33-1.98$ & -0.06 \\
\hline $\begin{array}{l}\text { Leader } \\
\text { support }\end{array}$ & 1.76 & $1.55-1.99$ & 0.01 & 1.67 & $1.37-2.04$ & 0.02 \\
\hline Role conflict & 1.74 & $1.54-1.97$ & -0.01 & 1.65 & $1.35-2.01$ & -0.02 \\
\hline $\begin{array}{l}\text { Emotional } \\
\text { demands }\end{array}$ & 1.65 & $1.45-1.87$ & -0.13 & 1.56 & $1.27-1.92$ & -0.15 \\
\hline $\begin{array}{l}\text { Hiding } \\
\text { emotions }\end{array}$ & 1.65 & $1.45-1.87$ & -0.13 & 1.53 & $1.25-1.88$ & -0.20 \\
\hline $\begin{array}{l}\text { Monotonous } \\
\text { work }\end{array}$ & 1.74 & $1.54-1.97$ & -0.01 & 1.64 & $1.34-2.00$ & -0.03 \\
\hline $\begin{array}{l}\text { Development } \\
\text { opportunities }\end{array}$ & 1.75 & $1.54-1.98$ & 0.00 & 1.66 & $1.36-2.02$ & 0.00 \\
\hline $\begin{array}{l}\text { Effort-pay } \\
\text { imbalance }\end{array}$ & 1.59 & $1.40-1.81$ & -0.21 & 1.53 & $1.25-1.87$ & -0.20 \\
\hline Bullying & 1.75 & $1.55-1.98$ & 0.00 & 1.66 & $1.36-2.03$ & 0.00 \\
\hline $\begin{array}{l}\text { Sexual } \\
\text { harassment }\end{array}$ & 1.74 & $1.53-1.97$ & -0.01 & 1.63 & $1.33-1.99$ & -0.05 \\
\hline $\begin{array}{l}\text { All psycho- } \\
\text { social factors }\end{array}$ & 1.59 & $1.40-1.81$ & -0.21 & 1.48 & $1.20-1.83$ & -0.27 \\
\hline \multicolumn{7}{|l|}{$\begin{array}{l}\text { Mechanical } \\
\text { factors }\end{array}$} \\
\hline Neck flexion & 1.73 & $1.53-1.96$ & -0.02 & 1.63 & $1.33-1.99$ & -0.05 \\
\hline $\begin{array}{l}\text { Hand-/arm } \\
\text { rep }\end{array}$ & 1.74 & $1.54-1.97$ & -0.01 & 1.64 & $1.34-2.00$ & -0.03 \\
\hline $\begin{array}{l}\text { Hands above } \\
\text { shoulder }\end{array}$ & 1.77 & $1.56-2.00$ & 0.03 & 1.69 & $1.39-2.07$ & 0.05 \\
\hline $\begin{array}{l}\text { Squatting/ } \\
\text { kneeling }\end{array}$ & 1.78 & $1.57-2.01$ & 0.04 & 1.71 & $1.40-2.08$ & 0.08 \\
\hline Standing & 1.74 & $1.53-1.97$ & -0.01 & 1.64 & $1.34-2.00$ & -0.03 \\
\hline $\begin{array}{l}\text { Upper-body } \\
\text { forward bend }\end{array}$ & 1.74 & $1.54-1.97$ & -0.01 & 1.66 & $1.36-2.03$ & 0.00 \\
\hline $\begin{array}{l}\text { Awkward } \\
\text { lifting }\end{array}$ & 1.76 & $1.55-1.99$ & 0.02 & 1.67 & $1.37-2.04$ & 0.02 \\
\hline Heavy lifting & 1.84 & $1.62-2.08$ & 0.12 & 1.71 & $1.39-2.09$ & 0.08 \\
\hline $\begin{array}{l}\text { Heavy physi- } \\
\text { cal work }\end{array}$ & 1.82 & $1.61-2.07$ & 0.10 & 1.73 & $1.42-2.12$ & 0.11 \\
\hline $\begin{array}{l}\text { Whole-body } \\
\text { vibration }\end{array}$ & 1.77 & $1.56-2.01$ & 0.03 & 1.69 & $1.38-2.07$ & 0.05 \\
\hline $\begin{array}{l}\text { Lifting } \\
\text { persons }\end{array}$ & 1.68 & $1.48-1.91$ & -0.09 & 1.61 & $1.32-1.98$ & -0.08 \\
\hline $\begin{array}{l}\text { All mechani- } \\
\text { cal factors }\end{array}$ & 1.79 & $1.57-2.04$ & 0.06 & 1.66 & $1.34-2.05$ & 0.00 \\
\hline Occupation & 1.66 & $1.44-1.90$ & -0.12 & 1.52 & $1.21-1.91$ & -0.21 \\
\hline $\begin{array}{l}\text { All variables } \\
\text { combined }\end{array}$ & 1.63 & $1.41-1.89$ & -0.16 & 1.43 & $1.12-1.82$ & -0.35 \\
\hline
\end{tabular}

a Physician-certified sick leave $>0$ days during 2010.

b Physician-certified sick leave $\geq 40$ days during 2010 .

c Percentage change in OR when comparing the initial OR to the further adjusted OR (ie, the initial OR adjusted for work-related factors). ${ }^{d}$ All models were adjusted for age, educational level, registered GSL or LTSL during 2009, working hours, working hours squared, housework and family status. ciated with a reduced gender difference were lifting of persons, neck flexion, hand/arm repetition and standing. In contrast, adjusting for heavy lifting, heavy physical work, and whole-body vibration increased the observed gender difference. In comparison with the initial model, adjusting for occupation reduced the OR by $12 \%$ and $21 \%$ for GSL and LTSL, respectively.

\section{Discussion}

This study investigated the role of work-related psychosocial and mechanical factors and occupation in explaining the gender difference in physician-certified SL in the general working population. After controlling for age, educational level, SL or LTSL in 2009, housework, working hours and family status, the present study found an approximately 1.7 -fold excess risk of both SL and LTSL among women. Psychosocial work environment factors explained about one-fifth and one-fourth of the excess risk of SL and LTSL, respectively. Work-related mechanical factors had minor overall impact on the observed differences. Differences between occupations held by women and men explained an additional onetenth of the excess risk for LTSL among women.

The strengths of this study are the large nationwide sample, the use of random sampling, and the prospective design, which measured a comprehensive set of work-related psychosocial and mechanical exposures. Even though a substantial percentage $(39 \%)$ of eligible respondents did not respond to the survey at baseline, those who did respond did not differ significantly on the benchmarks of age, sex, and region (31). The outcome measure was based on registry data and independent of the exposure data. Hence, loss to follow-up was not a problem in this study.

Despite a large variety of potential explanatory factors, nearly $80 \%$ of the gender differences in GSL and approximately 65 percent of the gender difference in LTSL could not be explained. Previous studies have designated pregnancy-related disorders as one of the most important factors explaining as much as $50 \%$ of the excess risk for sick leave among women (32). The "double burden" of combining paid work with family obligations (33) and women's tendency to show preventive health behavior (ie, taking a sick leave in order to prevent the worsening of complaints) have been discussed as important explanatory factors, but the evidence is scarce (6). Nevertheless, previous studies have shown that omitting women with pregnancy-related disorders from the analyses does not affect the explanatory effect of work on gender differences in physiciancertified sick leave $(2,10)$. Moreover, the present study indicates that the impact of working conditions on 
gender differences in sick leave is also independent of gender differences in non-work-related strain arising from parenting and housework. All exposure data were collected by self-report. Hence, bias due to error in the measurement of explanatory variables and other covariates cannot be ruled out. Although differences between occupations held by women and men explained a substantial part of the gender difference in perceived exposure to psychosocial work factors, it cannot be ruled out that gender-specific reporting style may have contributed to higher levels of perceived psychosocial workload among women.

The present finding that more than one-fourth of the excess risk of LTSL in women was explained by workrelated psychosocial factors is consistent with a comparable general working population study from Denmark (10). Moreover, the combined effect of psychosocial factors and occupation explained nearly two-fifths of excess risk of LTSL among women in the present study. A population study from Oslo concluded that the gender differences in sick leave could not be explained by specific working conditions (26); however, that study measured work-related psychosocial factors on two dimensions (low job control and shift work) and used a very crude measure of seven occupational groups. Studies that have applied a different statistical approach (fixed regression analyses) to control for detailed occupation groups have explained approximately $40 \%$ of the excess risk of physician-certified sick leave among female civil servants in Norway (22) and $30-50 \%$ of the excess risk among female municipal workers in Finland (24). In contrast, however, adjusting for occupation was reported to increase gender differences in sick leave in a general working population study from Norway (22). The fact that this previous general population study from Norway was based on data that are nearly 30 years older than the data in the present study and that a different statistical approach was applied may explain the different results. Firstly, adjusting for occupation using a fixed regression approach is based on the assumption that exposure levels are similar for men and women within the same occupation (24), but studies have shown that this assumption may be questionable $(8,13)$. Secondly, with a fixed regression approach, it is only possible to adjust for occupational categories in which both men and women are represented (22). In comparison, adjusting for a wide range of working conditions in the general working population makes no assumption of equal exposure levels for men and women, and does not require that both sexes are represented in any given occupation. Moreover, the approach chosen in the present paper provides information on the particular working conditions related to the observed gender difference in sick leave.

Emotional work and effort-payment imbalance were the most important explanatory psychosocial factors in the present study, which is also consistent with the Danish study (10). Moreover, quantitative demands and low job control appeared as important factors, consistent with studies demonstrating lower levels of job control among women (34). Previous studies on the importance of mechanical factors in explaining gender differences in sick leave have reported mixed findings $(10,23)$. The present analyses revealed a more nuanced picture, indicating that specific mechanical factors may have a different effect on the gender difference in sick leave. Lifting of persons was the single most important factor in reducing the gender differences in sick leave, which seems reasonable given that women are employed in healthcare occupations more often than men. On the other hand, adjusting for heavy lifting and heavy physical work increased the observed gender difference, consistent with the literature demonstrating a higher degree of physically demanding work among men (14).

In conclusion, work-related psychosocial factors contributed significantly to the excess risk of physiciancertified sick leave among women. Mechanical factors had a rather small overall impact on the observed differences.

Demands for hiding emotions, emotional demands, and effort-payment imbalance were the most important factors explaining the gender gap in sick leave. Other factors were low job control, high job demands, and the mechanical factor lifting of persons. These results were rather similar for physician-certified GSL and LTSL. The effect of occupation on the excess risk of sick leave among women was stronger for LTSL than GSL.

\section{Acknowlegments}

The author declares no conflicts of interest and this study received no funding. Statistics Norway carried out the survey according to statutory rules. Statistics Norway has appointed its own privacy ombudsman, approved by the Norwegian Data Inspectorate. All persons gave their informed consent prior to their inclusion in the study.

\section{References}

1. Hensing G, Andersson L, Brage S. Increase in sickness absence with psychiatric diagnosis in Norway: a general population-based epidemiologic study of age, gender and regional distribution. BMC Med. 2006;4:19. http://dx.doi. org/10.1186/1741-7015-4-19.

2. Laaksonen M, Martikainen P, Rahkonen O, Lahelma E. The effect of occupational and workplace gender composition on sickness absence. J Occup Environ Med. 2012;54(2):224-30. http://dx.doi.org/10.1097/JOM.0b013e318241ed42.

Scand J Work Environ Health 2014, vol 40, no 4 
3. Armannsdottir B, Mardby AC, Haukenes I, Hensing G. Cumulative incidence of sickness absence and disease burden among the newly sick-listed, a cross-sectional populationbased study. BMC Public Health. 2013;13:329. http://dx.doi. org/10.1186/1471-2458-13-329.

4. Johansen K, Bihrmann K, Mikkelsen S, Lynge E. Trends in sickness absence in Denmark. Scand J Work Environ Health. 2009;35(5):334-41. http://dx.doi.org/10.5271/sjweh.1346.

5. Barmby TA, Ercolani MG, Treble JG. Sickness absence: An international comparison. Economic Journal. 2002;112(480):F315-F31. http://dx.doi.org/10.1111/14680297.00046 .

6. Bekker MH, Rutte CG, van Rijswijk K. Sickness absence: A gender-focused review. Psychol Health Med. 2009;14(4):40518. http://dx.doi.org/10.1080/13548500903012830.

7. Statistics Norway. Statistical yearbook of Norway. Oslo: Statistics Norway; 2010.

8. Josephson M, Pernold G, Ahlberg-Hulten G, Harenstam A, Theorell T, Vingard E, et al. Differences in the association between psychosocial work conditions and physical work load in female- and male-dominated occupations. MUSIC-Norrtalje Study Group. Am Ind Hyg Assoc J. 1999;60(5):673-8. http:// dx.doi.org/10.1080/00028899908984490.

9. Charles M. Cross-National Variation in Occupational Sex Segregation. Am. Sociol. Rev. 1992;57(4):483-502. http:// dx.doi.org/10.2307/2096096.

10. Labriola M, Holte KA, Christensen KB, Feveile H, Alexanderson K, Lund T. The attribution of work environment in explaining gender differences in long-term sickness absence: results from the prospective DREAM study. Occup Environ Med. 2011;68(9):703-5. http://dx.doi.org/10.1136/ oem.2010.060632.

11. Allebeck P, Mastekaasa A. Swedish Council on Technology Assessment in Health Care (SBU). Chapter 5. Risk factors for sick leave - general studies. Scand J Public Health Suppl. 2004;63:49-108. http://dx.doi. org/10.1080/14034950410021853.

12. Lund T, Labriola M, Christensen KB, Bültmann U, Villadsen E. Physical work environment risk factors for long term sickness absence: prospective findings among a cohort of 5357 employees in Denmark. BMJ. 2006;332(7539):449-52. http:// dx.doi.org/10.1136/bmj.38731.622975.3A.

13. Hooftman WE, van der Beek AJ, Bongers PM, van Mechelen W. Gender differences in self-reported physical and psychosocial exposures in jobs with both female and male workers. J Occup Environ Med. 2005;47(3):244-52. http:// dx.doi.org/10.1097/01.jom.0000150387.14885.6b.

14. Campos-Serna J, Ronda-Perez E, Artazcoz L, Moen BE, Benavides FG. Gender inequalities in occupational health related to the unequal distribution of working and employment conditions: a systematic review. Int J Equity Health. 2013;12(1):57. http://dx.doi.org/10.1186/1475-9276-12-57.

15. Foss L, Gravseth HM, Kristensen P, Claussen B, Mehlum IS, Knardahl S, et al. The impact of workplace risk factors on long-term musculoskeletal sickness absence: a registry-based 5-year follow-up from the Oslo health study. J Occup Environ
Med. 2011;53(12):1478-82. http://dx.doi.org/10.1097/ JOM.0b013e3182398dec.

16. Frost P, Haahr JP, Andersen JH. Impact of work, health and health beliefs on new episodes of pain-related and general absence-taking. Scand J Public Health. 2009;37(6):569-76. http://dx.doi.org/10.1177/1403494809341094.

17. Holtermann A, Hansen JV, Burr H, Sogaard K. Prognostic factors for long-term sickness absence among employees with neck-shoulder and low-back pain. Scand J Work Environ Health. 2010;36(1):34-41. http://dx.doi.org/10.5271/ sjweh.2883.

18. Andersen LL, Clausen T, Persson R, Holtermann A. Doseresponse relation between perceived physical exertion during healthcare work and risk of long-term sickness absence. Scand J Work Environ Health. 2012;38(6):582-9. http://dx.doi. org/10.5271/sjweh.3310.

19. Rugulies R, Aust B, Pejtersen JH. Do psychosocial work environment factors measured with scales from the Copenhagen Psychosocial Questionnaire predict registerbased sickness absence of 3 weeks or more in Denmark? Scand J Public Health. 2010;38(3 Suppl):42-50. http://dx.doi. org/10.1177/1403494809346873.

20. Rugulies R, Christensen KB, Borritz M, Villadsen E, Bültmann U, Kristensen TS. The contribution of the psychosocial work environment to sickness absence in human service workers: Results of a 3-year follow-up study. Work Stress. 2007;21(4):293-311. http://dx.doi. org/10.1080/02678370701747549.

21. Head J, Kivimaki M, Siegrist J, Ferrie JE, Vahtera J, Shipley MJ, et al. Effort-reward imbalance and relational injustice at work predict sickness absence: the Whitehall II study. J Psychosom Res. 2007;63(4):433-40. http://dx.doi. org/10.1016/j.jpsychores.2007.06.021.

22. Mastekaasa A, Dale-Olsen H. Do women or men have the less healthy jobs? An analysis of gender differences in sickness absence. Eur Sociol Rev 2000;16(3):267-86. http://dx.doi. org/10.1093/esr/16.3.267.

23. Laaksonen M, Martikainen P, Rahkonen O, Lahelma E. Explanations for gender differences in sickness absence: evidence from middle-aged municipal employees from Finland. Occup Environ Med. 2008;65(5):325-30. http:// dx.doi.org/10.1136/oem.2007.033910.

24. Laaksonen M, Mastekaasa A, Martikainen P, Rahkonen O, Piha K, Lahelma E. Gender differences in sickness absence-the contribution of occupation and workplace. Scand J Work Environ Health. 2010;36(5):394-403. http://dx.doi. org/10.5271/sjweh.2909.

25. Mastekaasa A, Olsen KM. Gender, absenteeism, and job characteristics - A fixed effects approach. Work and Occupations. 1998;25(2):195-228. http://dx.doi.org/10.1177 /0730888498025002004.

26. Smeby L, Bruusgaard D, Claussen B. Sickness absence: could gender divide be explained by occupation, income, mental distress and health? Scand J Public Health. 2009;37(7):674-81. http://dx.doi.org/10.1177/1403494809344360. 
27. Mastekaasa A. Kjønnsforskjeller i sykefravær: Betydningen av omsorgsoppgaver og jobbegenskaper [Gender Differences in Sickness Absence - the Importance of Family and Job Characteristics] (in Norwegian). Tidsskrift for Samfunnsforskning. 1990;31(6):531-54.

28. Orhede E. Nordic cooperation in research on the work environment. Scand J Work Environ Health. 1994;20(1):65-6. http://dx.doi.org/10.5271/sjweh.1426.

29. Dallner M. Validation of the General Nordic Questionnaire (QPSNordic) for psychological and social factors at work. [København]: Nordic Council of Ministers; 2000:012.

30. Siegrist J, Starke D, Chandola T, Godin I, Marmot M, Niedhammer I, et al. The measurement of effort-reward imbalance at work: European comparisons. Soc Sci Med. 2004;58(8):1483-99. http://dx.doi.org/10.1016/S02779536(03)00351-4.
31. Statistics Norway. Samordnet levekårsundersøkelse 2009 -Tverrsnitt. Tema: Arbeidsmiljø [Coordinated Living Conditions Survey 2009 - Cross Sectional. Focus: Work environment).[Report in Norwegian]. Statistics Norway, Oslo; 2010.

32. Alexanderson K, Sydsjo A, Hensing G, Sydsjo G, Carstensen J. Impact of pregnancy on gender differences in sickness absence. Scand J Soc Med. 1996;24(3):169-76.

33. Mastekaasa A. Parenthood, gender and sickness absence. Soc Sci Med. 2000;50(12):1827-42. http://dx.doi.org/10.1016/ S0277-9536(99)00420-7.

34. de Smet P, Sans S, Dramaix M, Boulenguez C, de Backer G, Ferrario M, et al. Gender and regional differences in perceived job stress across Europe. Eur J Public Health. 2005; 15(5):536-45. http://dx.doi.org/10.1093/eurpub/cki028.

Received for publication: 22 October 2013 